Historic, Archive Document

Do not assume content reflects current scientific knowledge, policies, or practices. 



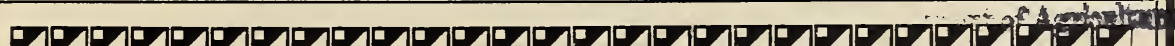

$1928-1929$

A. B. de Groat

Gladiolus Specialist

Bath, new York

Steuben County

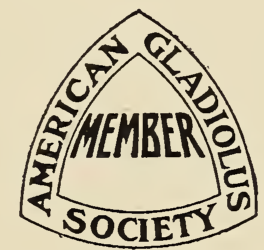

Member Empire State

Gladiolus Society

$\mathcal{A}$

LL GLADIOLUS enthusiasts receiving this catalogue can rest assured that I am presenting to you one of the finest collections ever offered. Where none are quoted in the hundreds, I cannot furnish them, except as per catalogue. Some years ago I placed on the American market Madam Mounet Sully, and from time to time I am placing more of the French varieties on the market. You are always sure of getting original stock from deGroat's. 


\section{PRICE LIST AND DESCRIPTION}

ALBANIA. A splendid white with wide open flowers four inches in diameter; petals broad with finely ruffled edges. 15e each. 12 for $\$ 1.50$.

ALICE TIPLADY. Popular orange prim. se each. 12 for 50c.

AMERICA. Large flower, flesh pink. 4e each. 12 for 40c. 100 for $\$ 3.00$.

ANNA EBERIUS. Deep Rhodamine purple, shading into very deep bordeaux center. 10c each. 12 for $\$ 1.00$.

ANNA LAURIE. A ruffled pink of exquisite beauty. Placed on the market last year for the first.35e each. 12 for $\$ 30$

BARON HULOT. Finest dark blue. te each. 12 for toc. 100 for $\$ 5.00$.

BETTY JOY. Soft creamy white flushed LaFrance pink, strong grower, long flower spikes with 6 to 10 perfect flowers opening at a time. 50c each. 12 for $\$ \$ 5.00$.

BEACON FLAME. A fine large red. 10c each. 12 for $\$ 1.00$.

BLUE JAY. Fine light blue, splashed with white. 15c each. 12 for \$1.50. 100 for \$12.00.

BREAK O'DAY. Massive spikes, color, LaFrance pink flushed over a cream ground and shade is deeper at tips of petals. Blooms extra early. In considered the most striking early variety ever produced. $25 \mathrm{c}$ each. 12 for $\$ 2.50$.

BYRON L. SMITH. Most refined lavender pink on white ground. Very fine as a cut flower. Color equal to an Orchid. 15e each. 12 for \$1.50.

CAPTAINE FERBER. Pale plum violet, spotted amaranth. French variety.

$25 c$ each. 12 for $\$ 2.75$.

CHARLEMAGNE. Very large, open flowers; color sunrise red, flaked darker; marked mašnificently. French variety. 10c each. 12 for \$1.00. 100 for \$9.00.

CHICADEE. Very dainty and airy, an extra early variety of merit, Eosine pink with light yellow blotches on lower petals. 10e each. 12 for 75 .

CRIMSON GLOW. Large crimson; best all around crimson ever offered, extra choice. 10c each. 12 for $\$ 1.00$. 100 for $\$ 8.00$.

DR. F. E. BENNETT. Deep peach red overlaid with flanıe scarlet; lip speckled ruby and white. Most fiery red imaginable. Flowers of the very largest size with many open at oncess each. 12 for 450

EARLY SNOWFLAKE. White, delicately flaked and tinted rose, with a barium yellow throat, slightly splashed with rose deep in throat. 10c each. 12 for \$1.00.

EDOUARD GREGG. Bright rose blotched amaranth. French variety. 50c each. 12 for \$5.50

E. J. SHAYLOR. Fine ruffled rose pink. 10c each. 12 for \$1.00.

ELECTRA. Bright and pleasing brick red; one of the earliest verieties. 10c each. 12 for $\$ 1.00$.

ELORA. White, slightly flushed pink; throat sulphur-yellow with a carmine blotch. A Burbank production, very early. 10e each. 12 for \$1.00.

ETENDARD. Cream white, center dark red; very fine French variety.

10c each. 12 for $\$ 1.00$. 100 for $\$ 9.00$.

EUGENE LEFEBVRE. Bright pink, throat spotted and dotted purplish amaranth and cream. French variety. 20e each. 12 for $\$ 2.00$. 100 for $\$ 15.00$.

ELROPA. A very fine white Glad of perfect iorm, mid-season. 15e each. 12 for \$1.50.

EVELYN KIRTLAND. Beautiful rose pink, darker at the edges, fading to shell pink at the center, with brilliant scarlet blotches on lower petals. Many open at one time. Tronderfully decorative. se each. 12 for $75 c$. 100 for \$8.00.

EMILE AUBURN. Immense blooms, coppery bronze blotched cherry. New Lemoine, in great demand.

GEN. LANGLOIS. Magnificent flower; maroon, interior petals spotted beautifully; another French variety. $25 c$ each. 12 for \$2.50.

GENERAL PERSHING. Large pale pink. 10e each. 12 for \$1.00. 100 for \$9.00.

GENERAL SUERDOFF. XXXX Light pale blue running into lavender. Interior petals spotted. $25 \mathrm{c}$ each. 12 for $\$ 2.75$.

GLADDIE BOY. A prize winner wherever shown. The color is very distinctive, the general effect being a Granadine pink, gradually blending with straw yellow deep in the center. The petals are most gracefully frilled. 50c each. 12 for \$5.00.

GLORIANA. A beautiful light salmon pink with cream yellow throat.

GOLDEN KING. Brilliant Golden yellow, with intense crimson bloteh in throat. One of the best yellows. Je each. 12 for 50c. 100 for \$4.00.

GOLDEN MEASURE. One of the finest yellows. Self color, strong spike. 15c each.

GIANT NYMPH. Immense rose pink flowers with creamy yellow throats borne on tall erect spikes, one of the finest. 25c each. 12 for \$2.50.

HALLEY. The earliest pink. 5e each. 12 for 56c.

HERADA. Pure mauve with deeper markings in throat. 10c each. 12 for \$1.00.

JACOBA VAN BEYREN. A recent introduction, fine variety. Extraordinary violet selfcolor, well placed on tall perfect splie. Growth strong, with a color that none other of its class can equal. 15c each.

JEAN du TAILLES. XXXX Large Salmon flowers, blotehed with maroon; another fine French variety. 15e each. 12 for $\$ 1.50$. 160 for $\$ 12.00$.

JENNIE LIND. Shrimp-pink deepening to Geranium pink at tips of petals. Flowers tubular. Spike compact. Flowers ruffled and edges rolled back. Should be in every high class collection. 20c each.

JEWELL. Rose pink shading into yellow. Extra fine. 15e each. 12 for \$1.50.

JOE COLEMIN. Ruffled red, many open. 10e each. 12 for \$1.00.

LA COLROLNE. Broad flowers. cream white, throat blotched and maroon. 25e each. 
LA MARECHAL FOCH. Very early. Chaming rose-pink, large flowers, wide open. 10c each. 12 for $\$ 1.00$.

LE CID. Large, brilliant scarlet; another fine French variety. 25e each. 12 for \$2.50.

LILLYWhite. Pure snow white. Very early. 10e each. 12 for $\$ 1.00$.

L'IMACULEE. A very fine white. 10e each. 12 for $\$ 1.00$. 100 for $\$ \mathbf{s . 0 0}$.

LitTle diAiond. Kunderd's ruffled pink, dainty. 16e each. 12 for \$1.9.

LOUISE. Very dainty lavencier, closely resembles a Cattlye orchid. 15e cach.

LCCETTE. As seen growing in the fields it appears to be absolutely pure white, but back of petals carry a trace of phlox pink which imparts an alluring orchid sheen to the flowers. 10e each. 12 for 7 se.

MADAM MIOUNET SULLY. Cream white with red center; one of the finest French varieties. Tery popular25e each. 12 for $\$$

MADAM SARAH BERNHARDT. Pale mauve pink, strong blotches of a crimson purple edged sulphur, very early. Exceptionally fine French variety.

25c each. 12 for $\$ 2.75$.

MARSHAL FOCH. Kunderd's large ruffled pink. Vory fine. 15c each.

MARY PICKFORD. White with lomon lip. 16c each. 12 for $\$ \mathbf{1 . 0 0}$.

MARY STEWART. Our own production. Creamy pink, deeper on tips, lower petals at base; blotched crimson on yellow ground. 1(ic each. 12 for $\$ 1.00$.

METEOR. Brick-red, Large. 11. each. 12 for $\$ 1.00$. 100 for $\$ \$ .00$.

MI. FERDINAND CAYEAUX. Dark yellow with reddish center. Fine French variety. 250 each. 12 for \$2.55.

MILADY. (Ruffled). Extra tall, strong ruffled variety of creamy white. Naples yellow throat with heary Amaranth purple feather. Very strong prolific grower.

10e each. 12 for 55 .

MIXTURE. Exceptionally fine mixture. 3e each. 100 for \$2.00.

MIRS. DOCTOR NORTON. White with edges suffused with pink; lower petals blotched sulphur vellow speckled with tyrian rose. This variety has received highest awards wherever exhibited. 15c each. 12 for $\$ 1.00$. 100 for $\$ \$ 9.00$.

MRS. F. C. PETERS. Amaranth pink with a purplish blot in the throat; tall straight spike. Many flowers open at once. 15e each. 12 for \$1.50.

MIRS. F. C. HORNBERGER. Without a doubt the world's finest white. \$1.00 each. 12 for $\$ 10.00$.

MRS. FRANCES KING. Flame pink; very popular. 4e each. 100 for \$\$3.00.

MRS. FRANK PENDLETON. Bright pink with two tones and rich carmine, very popular. 7c each. 12 for 75 c. 100 for $\$ 6.00$.

MIR. MARK. Light blue with dark spot. 15e each. 12 for $\$ 1.50 .100$ for $\$ 10.00$.

MR. W. H. PHIPPS. LaFrance pink overlaid with light rose salmon, lighter toward the center. Lower petals very faintly striped and speckled with ruby. Flowers enormous. A master-piece in Gladiolus. toe each. 12 for $\$ 3.75$.

MRS. W. E. FRYER. Poppy-red, with amber-white throat, and a bloteh of crimson-red. 6e each. 12 for 65e. 100 for $\$ 5.00$.

MRS. H. R. WHITNEY. A refined dark orange Prim; excellent for table decorations. 10c each. 12 for $\$ 1.00$.

MRS. LEON DOUGLAS. Enormous rose colored blossoms striped with scarlet. Extra long spikes. This is one of the largest "glads" in existence. Exceedingly beautiful. 25e each. 12 for \$2.50.

NIAGARA. Soft prinurose yellow-giant type, throat tinted with carmine. be each. 12 for tisc. 160 for $\$ 4.50$.

OPALESCENT. Wonderful spikes of very large pale rose lavender. A pure self color with soft lilac throat lines. $15 x$ each. 12 for $\$ 15 \%$.

PANAIIA. Pink seedling of America, but several shades darker; rery popular. sc each. 12 for 50c. 100 for $\$ 4.00$.

PEACE. Giant white, lower petals marked with dark carmine. be each. 12 for 50e. 100 for $\$ 4.00$.

PINK PERFECTION. Bright pink, very large flower. se each. 12 for s5c. 100 for \$5.00. PRIMULINUS. All yellow, popular, je each. 12 for soc.

PRINCE OF WALES. Delicate salmon pink, early. very popular. 16.e each. 12 for $\$ 1.00$. 100 for $\$ 7.00$.

PURPLE GLORY. One of Kunderd's best, deepest velvety maroon red, with almost black blotches like burned into the petals. 15e each. 12 for \$1.50.

PRIORITY. A beautiful pink, tall, straight and strong; Venetian pink, shading darker toward the tips; faint central lines and feather of deep rose pink. A sure winner. 15e each. 12 for $\$ 1.30$.

QUEEN OF THE BLACKS. XXXX Very dark red; a distinct novelty; finest dark we know of. Rare. 15e each. 12 for $\$ 1.50$. 100 for $\$ \$ .00$.

RED EMPEROR. Large deep scarlet of immense size. 15e each. 12 for \$1.50.

ROSE ASH. One of the most popular flowers in any garden. The color is old rose, blended with ashes of roses; wonderful combination of colors; ruffled, tall, straight spikes: always attracts the eye. 1Ce each. 12 for $\$ \mathbf{\$ 1 . 0 0}$.

SCRIBE. Tinted white, streaked with fine crimson. 10e each. 12 for \$1.00.

SCHWABEN. Sulphur yellow with crimson stripes; extra fine. 7e each. 12 for 70 .

TRIOMPHE de CAIN. White slightly tinted with rose. Fench variety.

me ench. 12 for wa.5. 


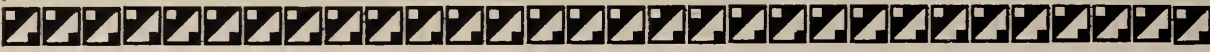

TYCKO ZANG. Salmon pink blooms over five inches in diameter, with usually four petals per large bloom averaging two inches in diameter. Spike fifty-three inches tall. s0e each. 12 for $\$ 2.50$.

THEDA. Large shrimp-pink blossoms with soft yellow throat; tall stems, extra early, much admired at our gardens this past season. 10e each. 12 for $\$ 1.00$.

VANITY. Delicate LaFrance Pink flushed over cream ground; very large flowers of airy graceful type with slightly reflexed petals. 15e each. 12 for $\$ 1.50$.

WABAN. A fine bright red, new. 2se each.

WAR. Extra dark scarlet. 6e each. 12 for 65e.

WHITE WONDER, Almost pure white; faintly flaked rose-pink. A very large flower well set on the spike and many open at a time. Very popular. ise each.

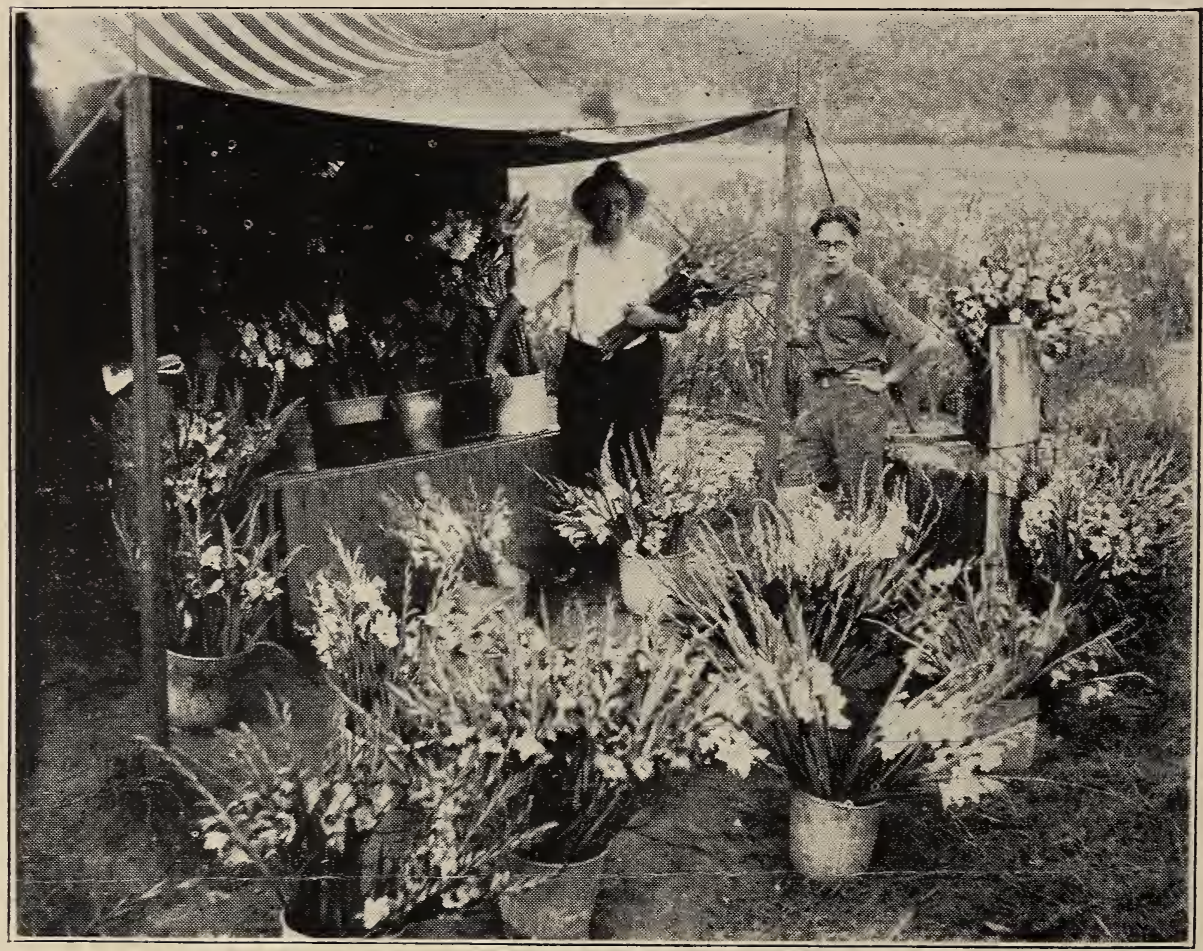

At Our Gardens During 1928 Season

Thousands of Visitors

you Are Welcome? 